of his presidential address the "Safety and Health of Mineworkers". He further contributed to the Transactions of the Institution of Mining Engineers "Some Notes on a Visit to Germany" and was the author of five special reports on colliery disasters at Bilsthorpe (1934), Markham (1937), Barnsley Main (1942), Manvers Main (1945), and Harrington (or Lowca) in 1947.

His recreations were reading and almost certainly writing, for his penmanship was outstandingly good. He had a deep love of music and of church music in particular. He was organist and choirmaster at Methodist churches at West Stanley and elsewhere, for as he moved about the country he remained until the end a devout and active church member.

Sir John was a man of wide and deep sympathies, greatly interested in the welfare of young people and for many years associated with the National Children's Homes. He was also very much concerned with the welfare of old people and took a leading part in the provision of houses for them in the Sutton district.

His wife died in 1936 and his only child, a daughter, in 1953. In recent years he had been greatly troubled by failing eyesight, but he bore all his misfortunes with fortitude and invariable cheerfulness.

T. A. Rogers

\section{Prof. A. J. Grove}

Alfred John Grove, professor emeritus in the University of London, who died on June 5 at the age of seventy-four, held from 1947 until his retirement the newly created chair of zoology at Queen Mary College. Indeed, this appointment was largely a tribute to his work in building up the Department from small beginnings during the years 1929 and onwards.

Grove took his first degree at Birmingham when he was only nineteen and was at once awarded a scholarship to work on entomological problems. A series of papers, mainly on the functional morphology of insect mouth parts, was recognized by the award of the D.Sc. degree of that University, and soon by the grant of an 1851 Exhibition which took him to Cambridge in 1910, where he continued his studies for a year as a member of Emmanuel College. From 1911 until soon after the outbreak of the First World War, Grove was employed as an entomologist in the Indian agricultural service, but he was then drawn back into university life as a lecturer at his old University. When it became apparent that there was a need for medical entomologists, Grove volunteered for service in the Royal Army Medical Corps and worked with teams controlling malaria in the Middle East, particularly in Palestine. He resumed his interrupted academic career by accepting a lectureship in the University of Sheffield shortly after the War ended and stayed there until 1929, when he joined G. P. Mudge in the small department at East London College (as Queen Mary Collego was then called). Up to that time the department had been solely concerned with preparing students for first medical examinations, but now it began to accept students for general and special degrees in zoology. Re-equipment and expansion were inevitable and in 1936 the department moved, with Grove as its head (Mudge having retired), into new quarters in the newly built west block, where it is still housed.

The Second World War put a brake on further material progress, for in 1939 a greatly diminished
Queen Mary College was moved to Cambridge for the duration of the War, but there can be no doubt that the war years spent in the stimulating atmosphere of Sir James Gray's Department was of lasting benefit to Grove and his colleagues ; it is a pleasure to place on record that this is still remembered with gratitude. The happy relations between the two Zoology Departments was in no small measure due to Grove's eagerness to co-operate and to take full advantage of the splendid resources put at his disposal.

Grove will be remembered by his colleagues as an authority on the reproduction of earthworms as well as for his contributions to insect morphology, while many generations of students are grateful for his text-books and laboratory manuals which bear witness to his ability as a meticulous teacher. Grove took a full share in examining for the University of London and never shirked any of the onerous and time-consuming administrative duties inevitable in a large university either within the College or at the Senate House and by the time he retired he had been a dean for many years and chairman of several important committees, posts which he filled with great success. $\quad$ G. E. NEwELL

\section{Prof. Franciszek Adamanis}

Poiss pharmacy suffered a great loss when Prof. Franciszek Adamanis, professor of pharmaceutical chemistry at the Medical Academy in Poznan, died of cancer on April 14. His intellectual qualities, combined with his open-hearted friendliness, earned him the respect and affection of many pharmacists abroad as well as in Poland. His own interests and affections were deeply connected with the profession of pharmacy. He was a champion of the improvement of the status of this profession, in opening the door for a pharmacist to the analytical and biochemical laboratories and to the pharmaceutical industry. The aim of his life was to gain recognition for pharmacists in the fields of analytical chemistry, biochemistry and microbiology.

Franciszek Adamanis was born in Libawa (Latvia) on October 4, 1900. He finished his secondary education in Homl (Russia) in 1918 and entered the Faculty of Law in the University of Poznan. Later, he became a member of the Faculty of Pharmacy, and in 1927 he gained his Master's degree for work on Heinz Aldol. For his first scientific work he was awarded the bronze medal by the Senate of the University.

In the same year he started to work as an analytical chemist in the chemical industry and in 1929 he became a director of the firm Akwawit in Poznan. In 1930 he started to work on his Ph.D. thesis under the guidance of Prof. Konstanty Hrynakowski. $\mathrm{He}$ studied the additive combinations of the molecular compounds of urea by the method of thermal and optical analysis. He determined the forces of co-ordination existing between components of the molecular compounds and the effect of these forces on the biological action. $\mathrm{He}$ also pointed out the relation between the additive properties of tri-valent nitrogen and its pharmacological action. The very promising results of his research made possible his graduation for Ph.D. in 1932 and his habilitation for docent in 1937.

After the death of Prof. Hrynakowski in 1938, he became the head of the Department of Pharmaceutical Chemistry at the University of Poznan. 
After the outbreak of the Second World War he was taken prisoner and sent to the concentration camp in Gusen, Austria, from 1940 until 1945. The deep honesty of his character helped him to maintain an inflexible position. In trying to save the lives of many people, he organized the production of drugs in the simple and primitive conditions of the camp's labora. tory. He distributed more than 40,000 ampoules of injections among people, running the risk of losing his own life every day.

After the War he returned to Poland and started to rebuild from the ruins of the University of Poznan the Department of Pharmacentical Chemistry. His post-war scientific work extended into two main efforts. First, he pioneered the teaching of pharmaceutical chemistry and the change of the old tradi. tional programme which was based on the division of drugs according to their chemical structure. In his book Chemia Lekow, which appeared in three editions, he presented a modern approach in chemistry of drugs, giving their division from the pharmacological point of view. The post-war research mainly concerned the adaptation of modern analytical methods, for example, chromatography to the analysis of active substances of plants, especially alkaloids and glycosides. Another line of research which resulted from his analytical school was that on the stability of drugs, which will be continued by his disciples. $\mathrm{He}$ was the author of 75 original research papers and several theoretical reviews. He guided Ph.D. theses for 19 pharmacists.
In 1946 Adamanis was nominated professor of pharmaceutical chemistry, and in 1958 he became full professor. In addition, he was director of the State Institute of Medicinal Plants in Poznan until 1954, and dean of the Faculty of Pharmacy during the academic year 1951-52; for the past four years he was pro-rector of tho Medical Academy in Poznan. He took part in several international conventions of pharmacists and worked as an active member of scientific and pharmaceutical organizations. He was a member of the Committee of Pharmaceutical Sciences at the Polish Academy of Science, president of the Section of Pharmacy at the Poznan Society of Friends of Science, president of the Polish Pharmaceutical Association from 1960, member of the Polish Pharmacopoeia Commission, vice-president of the Section of Medicine at the Main Council of the Ministry of Education, and member of the American Pharmaceutical Association. In addition to this, he took part in work of social organizations. His great endeavours were rewarded by the City of Poznan and by the Government.

Adamanis was a man with an unusual background who had a variety of interests : his knowledge of Russian literature was exceptional, and he was an expert in architecture and sacral art. His main 'hobby' was photography, and he was also a strong supporter of the cultural background of his students. Now death has taken this great man, whose deep honour and honesty will remain the ideal for all future pharmacists. Danuta MaLeJka

\section{NEWS and VIEWS}

\section{Calfornia Institute of Technology}

ON June 30, four distinguished scientists retired from their chairs in the California Institute of Technology, each having reached the full retiring age of seventy: the honour of professor emeritus has been awarded to them.

\section{Prof. A. H. Sturtevant}

Prof. A. H. Sturtevant was Thomas Hunt professor of genetics. Ho has been at the Institute since 1928. He was a member of Morgan's original 'Drosophila group' that pioneered the new science of genetics, largely through the study of the Drosophila fruit fly. Among many major contributions, Prof. Sturtevant demonstrated that the genes lie in linear order and he helped to develop chromosome theory. Prof. Sturtevant is the author or co-author of 137 scientific publications, including several books. Among the books are An Introduction to Genetics, written with Dr. George W. Beadle, formerly of the Institute and now president of the University of Chicago, and Genetics and Evolution, a collection of Prof. Sturtevant's scientific papers selected by Dr. E. B. Lewis, professor of biology in the Institute.

\section{Prof. C. C. Lauritsen}

Prof. C. C. Lauritsen was professor of physics, and pioneer in nuclear physics and rocket research. $\mathrm{He}$ has been on the faculty of the Institute since 1929. He was one of the pioneers in research in the field of nuclear physics, and under his leadership the Kellogg Radiation Laboratory has, for three decades, been one of the world's leading centres of nuclear studies. Prof. Lauritson was also scientific director of the very large and active rocket-development group at the Institute during the Second World War, and in subsequent years became one of the leading advisers to the Government on military and scientific matters. He received the Medal of Merit for his war work. In addition to serving as technical consultant to the Army, Navy and Air Force on nuclear weapons and rockets, he spent a year at Los Alamos as special consultant on the atomic bomb project. He also helped formulate plans which led to the establishment of the Office of Naval Research.

Prof. E. C. Watson

Prof. Earnest C. Watson, professor of physics, was formerly dean of the faculty, and one of the buildors of the California Institute of Technology. Since 1960 he has boen on leave as scientific attaché to the U.S. Embassy in India. He supervised the planning and development of the well-known Norman Bridge Physics Laboratory at the Institute. His wife, Jane Werner Watson, is the author of nearly two hundred children's books.

Prof. F. J. Converse

Prof. F. J. Converse is an authority on soil mechanies. He is president of the Converse Foundation Fngineering Co. and has been consulted as a foundation engineer in the construction of many dams, tunncls, factories, military installations, shipyards, airports, power plants and sub-stations throughout the United States, and has done such specialized jobs as investigating the ground settling at Torminal Island. 